\title{
AMERICAN LEGAL COMMENTARY ON THE DOCTRINES OF MUNICIPAL TORT LIABILITY
}

\author{
John St. Francis Repko*
}

Factual research has not been a characteristic of the work of the legal commentator. Typically, the legal scholar has been concerned with legal doctrine and has appraised it from the standpoints of its internal logic, of its consistency with other legal principles, and of the persuasiveness of the reasons advanced by the courts and commentators in its support. Arguments based on experience are weighed in the scales of the commentator's own observation and judgment, his "common-sense knowledge."

There has been no dearth of such consideration of the law of municipal tort liability. A relentless barrage of unsympathetic criticism has been directed against the concept upon which the structure of the tort law of municipal corporations has been built. That concept, stemming from the eighteenth and early nineteenth centuries, ascribes to a municipal corporation a dual personality, one aspect of which is irresponsible in its sovereignty, the other answerable to the sanctions of private law. ${ }^{1}$ Although critical comment appeared before I900, widespread interest in the problem among legal commentators seems first to have been stimulated in 1924 by a notable series of articles ${ }^{2}$ by Professor Edwin M. Borchard of the Yale University School of Law. Since that date there have appeared in the law reviews alone over two hundred leading articles and student comments on pertinent judicial decisions. ${ }^{3}$ It is the purpose of this article to gather a representative sampling of that comment and criticism and to present it in the context of the rules and reasoning to which it has been directed.4

* A.B., I939, Temple University; LL.B., I942, Duke University. Editor, Duke Bar Association Journal. I940-I942.

1 That concept has been succinctly stated by Professor Charles W. Tooke: "The doctrine is that a municipal corporation is not liable to respond in damages for the negligence of its officers, agents or employees when they are acting in discharge of public or governmental functions. . . . On the other hand, the municipality will be held liable for the negligent acts of its offeers and agents acting within the scope of their authority, when they are performing functions that are classified as corporate or proprictary." Tooke, The Extension of Municipal Liability in Tort (1932) 19 VA. L. REv. 97, 100.

${ }^{2}$ Borchard, Government Liability in Tort (1924-r925) 34 YALE L. J. I, 129, 229; (1926-1927) 36 id. I, 757, 1039; (1928) 28 CoL. L. REv. 577, 734.

${ }^{3}$ A large number of the student notes and comments go no further than compiling the lines of authority, such critical comment as they contain being often limited to a general commitment to Professor Borchard's analysis. The treatise writers usually limit their criticism to particular applications of the rules, rarely challenging the soundness of the doctrine itself; but $c f$. HARPER, TORTS (I933) \$295.

- Citation of cases supporting the statements herein of legal principles and judicial rationale has becn generally omitted. The reader will find abundant reference to pertinent cases in the articles, notes and comments cited. 


\section{The Eariter Crittcs}

Long before Mr. Borchard ${ }^{5}$ prompted the flow of lawyer's ink against the simple conceptualism to which the courts feel bound, Professor Goodnow of Johns Hopkins, the distinguished pioneer in the field of American administrative law, had turned his attention to the tort law of municipal corporations and found it in sorry plight. His analysis, published in 1895 , led him to conclude that "the confusion . . . was due very largely to the [judiciary's] attempt to transfer into the law relative to municipal corporations and public corporations generally, the principle of the irresponsibility of the state." The confusion resulted, he felt, because the courts failed to perceive the true basis for sovereign immunity and therefore gave it an unwarranted extension. Sovereign immunity is due not to something inherent in the corporate character of the state, but rather it results "from the assumed impolicy of admitting that the government, the representative of the sovereign, can do a wrong for which it may be held liable."7 Where it is not impolitic to impose liability, all arguments for the application of the immunity principle fall. "If this is true of the position of the state, if the logic of the law, as the law of France and Germany would seem to show, does not require that the state should be held irresponsible where it enters into private relations with an individual, how much more necessary," he asks, "is it in the case of these quasi-public bodies, such as municipal corporations . . . to recognize that when they enter into private relations they should be held liable to all the duties imposed upon individuals by private law."8

While the bifurcation of the municipal entity springs from the 1842 case of Bailey v. The Mayor of New York, ${ }^{9}$ the applicability of the principle of the immunity of the sovereign to a lesser unit of government finds its beginnings in I788 in the oftcited case of Russell v. Men of Devon. ${ }^{10}$ In I92I, Professor Albert J. Harno demonstrated that neither the interpretations of that case, the reasons assigned in support of its purported holding, nor the reliance placed upon it are justified in the light of its facts and the reasons given in the case itself. ${ }^{11}$ The non-liability of the County of Devon was due more to the practical circumstance of an empty treasury and a hazy conception of corporate entity than to some inherent righteousness in sovereignty. After examining the latter-day reasons assigned to support the principle, Mr. Harno found the rule of immunity to be "socially indefensible . . . and all the reasons ad. vanced for upholding it . . . fallacious, and with all respects for honored precedent," he believed that the "courts should cease dealing with empty fictions and substitute therefor good sense."12

\footnotetext{
¿ Supra note 2.

${ }^{\circ}$ Goodnow, Municipal Home Rule (I895) I80. Professor Goodnow's treatment of the subject appears in chapters VII and VIII. His criticism is most vigorous in his discussion of torts arising from the use of municipal property, c. VIII.

${ }^{7}$ Ibid.

${ }^{8}$ Id. at $18 \mathrm{r}$. $\quad{ }^{8} 3$ Hill 53 I (N. Y. 1842 ).

${ }^{10} 2$ T. R. 667, roo Eng. Rep. 359 (1788). Apparently the first American decision to adopt the rule of this case was Mower v. Inhabitants of Leicester, 9 Mass. 247 (I812).

${ }^{11}$ Harno, Tort Immunity of Municipal Corporations (192I) 4 ILI. L. Q. 28.

${ }^{12} I d$. at $3 \mathrm{I}$.
} 


\section{Present-Day Criticism}

With the series of searching articles referred to above, Mr. Borchard challenged the very foundation of sovereign immunity as expressed in the maxim that the king can do no wrong, and asserted that it was introduced, without sufficient understanding, into America as part of the common law, surviving mainly by reason of its antiquity. ${ }^{13}$ Turning his attention particularly to the tort law of municipal corporations, he found the courts "laboring under a supposed inexorable domination of formulae, phrases and terminology, with the result that facts have often been tortured into the framework of a formula, lacking in many cases any sound basis of reason or policy."14 These are the notes which dominate the crescendo of voices raised against the tort law of municipal corporations: first, they condemn the insistent judicial adherence to the common law formula for which they say there is no justification; and, second, they deprecate the Procrustean techniques employed by the courts in their efforts to bring the varying circumstances of the modern municipal corporation with its diversity of functions into conformity with that formula.

It is a common charge that not only is there irreconcilable conflict in the classification of most of the newer and some of the older municipal functions but that even within any one jurisdiction a consistent pattern cannot be worked out from the cases. The conflict and confusion, the "unplanned arrangements of partial liability," "the spotted and striped law," which the commentators find in their researches, they attribute to the judicial compromise between the unfairness of complete immunity and the dread of complete liability. ${ }^{15}$ To synthesize briefly their analyses, ${ }^{10}$ the fault appears to derive from a lag between common law conceptualism and modern realism. As many of the critics see it, the extension of sovereign immunity to a quasipublic body occurred in the philosophy of one day and without serious judicial or legislative re-examination has been allowed to continue in that of another. In the time of Russell v. Men of Devon ${ }^{17}$ the courts had but a clumsy appreciation of corporate entity and were further troubled with the difficulties of distributing liability over the component members of that body. When Bailey $v$. The Mayor of New York ${ }^{18}$ was decided American cities were just beginning to assume an importance

${ }^{13}$ Borchard, Government Liability in Tort (1924) 34 YALE L. J. I, 2: "The facts that the conditions which gave it birth and that the theory of absolutism which kept it alive in England never prevailed in this country and have since been discarded by most monarchical countries of Europe, have nevertheless been unavailing to secure legislative reconsideration of the propriety and justification of the rule that the State is not legally liable for the torts of its officers."

${ }^{24}$ Id. at $\mathrm{x}$.

${ }^{16}$ Fuller and Casner, Municipal Tort Liability in Operation (1941) 54 Hasv. L. Rev. 437; Borchard, supra note 13, at $x$; Note (I929) I4 CoRN. L. Q. 35I, 355.

${ }^{10}$ The synthesis which follows is a composite drawn principally from the following: Murray, Recent Trends in Municipal Tort Liability (1940) 5 LegaL Nores oN LOCAL GovT. 353; Rosenficld, Governmental Immunity from Liability for Torts in School Accidents (1940) 5 LEGAL Notes ON LOCAL GovT. 358; Seasongood, Municipal Corporations: Objections to the Governmental or Proprietary Test (1936) 22 VA. L. Rev. 910; Tooke, The Extension of Municipal Liability in Tort (1932) 19 VA. L. Rev. 97; Fcczer, Capacity to Bear Loss as a Factor in the Decisions in Certain Types of Tort Cases (1930) $78 \mathrm{U}$. or $\mathrm{PA}_{\mathrm{A}}$. L. REv. 8xo, 815 .

I" Supra note ro.

${ }^{28}$ Supra note 9. 
on the social and political horizon. There was a fear that an unrestrained demand to satisfy tort judgments from public treasuries would stunt their growth. It was therefore thought wiser to let the loss lie where it had fallen in certain instances than to risk an obstruction in the development of this important unit of government and civilization. The concentration of population and machinery in cities, however, increased the demands made upon them. And, as the municipal corporation grew in size, as it assumed more and more services and functions, so too did its potentiality for the infliction of harm increase. With the growing complexity of life the cost of doing business came to include such things as workmen's compensation and pension funds. In the field of tort law capacity to bear loss became a factor in the decisions, and the principle of vicarious liability received new emphasis and import. The pendulum was swinging to the other end of its arc so that it came to be a better thing to distribute unavoidable loss over as wide an area of absorption as possible.

The commentators recognize that courts were not unaware of these trends. But the judicial process of readjustment to changing values is a slow and hesitant one. Met with an impasse of precedent the courts have consistently refused to renounce the common law formulae; rather they view them as inevitable and inexorable in the absence of legislative redirection. Consequently such response to the changed philosophy as they have made has been within the confines of stare decisis by way of distinctions, refinements, escapes and exceptions; tactics which the commentators claim lead but to confusion and conflict in which the predictive value of stare decisis is lost.

Despite the criticism, there has been almost no judicial retreat from the doctrine that a municipal corporation enjoys partial immunity. The South Carolina court, however, feeling the classification of municipal functions into the mutually exclusive categories of "governmental" and "proprietary" a hopeless task, broke with precedent and now applies a consistent rule of immunity unless otherwise directed by the legislature. ${ }^{19}$ Ohio, on the other hand, took a somewhat hesitant step toward a uniform rule of liability but in quick time retraced it and is now back in line..$^{20}$ Florida, taking its cue from Ohio, seems to have departed from the usual approach by use of a presumption against the municipal corporation but how far this will take the courts of that state is not yet clear. ${ }^{21}$ Elsewhere the notion of functional dualism

\footnotetext{
${ }^{10}$ In Irvine v. Town of Greenwood, 89 S. C. 511, 517, 72 S. E. 228, 230 (I9II) the court said: "The confusion which has resulted from the refinements and distinctions attempted by other courts with respect to the liability of municipal corporations for torts committed by officers or employees is so great that it would be difficult, if not impossible, to deduce from them a rule which could be applied with confidence by the public or the bar."

${ }^{20}$ Fowler v. City of Cleveland, I00 Ohio St. I58, 126 N. E. 72 (I919), overruled by Aldrich v. Youngstown, 106 Ohio St. 342 , I40 N. E. I64 (Ig22). It is a matter of some speculation whether the New York courts are not now ready to overrule the doctrine and apply a rule of liability; see Osipoff $v$. City of New York, 286 N. Y. 422,36 N. E. (2d) 646 (1941), wherein the court quotes, without comment, a passage from Harper, Torts $\$ 295$, which is sharply critical of municipal immunity and which concludes: "The principle can find no justification in sound social policy and is one that is productive of great injustice and hardship to individuals with but slight corresponding advantage to society."

${ }^{21}$ Kaufman v. Talahassee, 84 Fla. 634, 94 So. 697 (1922); see Note (I94I) I5 FLA. L. J. 223.
} 
persists, firmly entrenched by precedent and avoidable only by an exercise of delicate judicial ingenuity or direct legislative assault.

Preliminary to a report of the commentator reaction to the judicial rationale and technique employed in the decisional law of this subject, it should be pointed out that the distinctions inherent in the concept of dual capacity have no place in at least two instances. ${ }^{22}$ The furst of these is where the alleged injury is the result of a direct trespass to property. If the municipal corporation, through its council or governing body, authorizes or ratifies an invasion of the property rights of an individual an action of trespass seems to lie without concern over the nature of the function in which the tort was inflicted. It is only when the municipal corporation can point to an express or implied authorization from the state legislature to construct the public work or other improvement in the injurious way in which it was built that it can "shield itself behind the State's alleged impossibility to commit or authorize a tort."23

The second instance is presented by cases where the court finds the municipal corporation to have caused the injury complained of by creating, maintaining or tolerating a nuisance. A distinction, however, is usually made between injuries to person and injuries to property. If the same nuisance causes both a personal and a property injury, recovery will be granted for the latter harm and denied as to the other. It thus seems that the courts are prone to protect a person more assiduously in his property rights than in the inviolability of his person. The distinction has not received the approval of any commentator. "Whether this difference," to quote Professor Borchard, "can be satisfactorily explained ... by the fact that the governing authorities acting as the corporation are presumed to be aware of continuing nuisances, whereas the defective condition of public property causing personal injuries is usually due to the negligence of some individual caretaker, is more than doubtful."24 Relatively recent writers, however, note a tendency to expand the nuisance theory so as to include personal injuries. ${ }^{25}$ It also seems to be a widespread opinion among the commentators that the nuisance theory is being more frequently resorted to as an escape from the inflexibility of the governmental-proprietary formula; they believe that the courts are taking almost every occasion to find a nuisance so that liability can be imposed without too great a distortion of the common-law distinction. ${ }^{26}$

${ }^{22}$ For other instances where the usual tests of liability are disregarded, see Seasongood, Municipal Corporations: Objections to the Governmental or Proprietary Test (1936) 22 VA. L. Rev. 910, 917.

${ }^{23}$ Borchard, Governmental Liability in Tort (1925) 34 YALE L. J. 129, 138; see also David, Municipal Liability in Tort in California (1934) 7 So. Calif. L. Rev. 214; (1939) 37 Mrch. L. Rev. 809; (1931) 20 Nat. Munic. Rev. 540.

${ }^{24}$ Borchard, supra note 23, at r39; see also (I94I) 25 MARQ. L. REv. I05.

${ }^{25}$ David, stepra note 23, at 215; Note (x941) X9 NoTre DaMe Lawyer 365; Note (1940) 28 Geo. L. J. 526; (1938) 22 MaRe. L. Rev. 158; (r93I) 20 Nat. Munic. Rev. 540; but cf. (1936) 35 Micir. L. REv. 157 .

${ }^{20}$ See note 25 , supra. For a consideration of the Wisconsin limitation on the nuisance doctrine, sce Note (I94I) WIS. L. REv. 554. 
Tests of LiabiLity

I. Governmental and Proprietary. The point of beginning and return in almost every tort case in which the defendant is a municipal corporation is the classification of the function in the course of which the alleged tort was committed in terms of "governmental" or "proprietary," or into one of the several other alternative pairs of antonyms. ${ }^{27}$ Unless the plaintiff's complaint shows that the source of his trouble is one of the few excepted categories noted above, his initial task is to rebut the municipality's challenge that the function involved was one appertaining to government.

The most usual judicial rationale for immunity in the pursuit of governmental functions is that when a municipal corporation is acting in that capacity it is acting as an arm of the state. The state is not subject to suit in tort; therefore, its anatomical appendage enjoys a like immunity. The critics' answer ${ }^{28}$ to this is that a state enjoys immunity, not because of any inherent perfection, but rather because of a lack of remedy against it. The state is not subject to the jurisdiction of its courts. It can, however, and often does consent to suit. "A municipal corporation," to quote Mr. Harno, "is not at all in the same position. It, as a rule, can be sued, and is amenable to process for the purpose of compelling it to perform its obligations. The courts have adequate jurisdiction over municipal corporations."29 Consequently, where both the wrong and jurisdiction over the wrongdoer exists, immunity cannot be justified by this analogy. ${ }^{30}$ Some other consideration must be looked for.

A related justification is that in the performance of governmental functions the municipal agents and employees are acting as agents and employees of the state. The rule of respondeat superior has no application, nor could it in this view impose liability on the municipal corporation. But, point out the critics, the fact of agency" or a master-servant relationship is not normally determined by the character of the service or function in which the tort was committed, but by the control exercised over the agent or employee. He who has authority to employ and dismiss another, to direct and control the work, is master; he who must submit to such direction and control is agent or servant. There is no doubt that in almost every case this direction and control is centered in the municipal corporation. The critics ${ }^{31}$ insist that a

${ }^{27}$ The term "governmental" is used in the decisions interchangeably with the terms public, sovereign, political, state, mandatory, essential, discretionary, legislative. The term "proprietary" is used interchangeably with the terms private, corporate, quasi-private, non-governmental, non-essential, ministerial, commercial, permissive. "Discretionary" and "ministerial" are also employed by some courts in a manner suggesting an independent test. This is discussed at pp. 222-223 infra.

${ }^{38}$ Peterson, Governmental Responsibility for Torts in Minnesota (I942) 26 MrnN. L. Rev. 293, 337; Seasongood, supra note 16 , at $9 \mathrm{r} 3$; Harno, supra note $\mathrm{Ir}$, at 34 .

${ }^{20}$ Harno, supra note II, at 34 .

${ }^{30}$ See Workman v. New York City, I79 U. S. 552, 566 (I900).

31 Harno, supra note II, at 34; see also Clarke, Municipal Responsibility in Tort in Maryland (1939) 3 Mo. L. Rev. 159, x62; Freedman, Liability in Tort of Municipal Corporations in Missouri (1938) 3 Mo. L. REv. 274, 277; Seasongood, supra note I6, at 912; David, supra note 23, at 3ro; Borchard, supra note 23, at 134; Albertsworth, Recognition of New Interests in the Law of Torts (I922) Io CaLIF. L. REv. 46I, 485; (1938) II Rocky Mr. L. REv. 49; but cf. (I938) 2 TEMP. L. Q. Igo. For a consideration of the W. P. A. cases, see (1938) 7 Geo. L. Rev. 265. 
normal application of the rules of agency would reveal the city as the principal or master. They can neither find nor imagine a reason for a different or a distorted rule of agency; "it surely is not logic."

It is urged by a few courts that in performing governmental functions the officers or agents of the city owe no duty to the injured individual; that such duty as exists is one running to the sovereign state. From this premise it follows that no wrong has been done the injured party for there was no breach of duty to him. In a recent article, Mr. Orville C. Peterson ${ }^{32}$ points out that this reasoning is a petitio principii, its premise its own conclusion. He finds it impossible to tell from the cases indulging in this question-begging whether there is no duty because the function was public, or the function public because there was no duty.

Some courts have justified the rule of immunity as one necessary to prevent the diversion of public funds to private or unauthorized purposes. So deeply entrenched is this fear of an empty purse that it has been held improper to reimburse an official who had been held to personal account by his victim for a tort committed in the performance of his official duties. The commentators are of the opinion that such a stand as this evidences a philosophy of risk allocation contrary to that which inspired the workmen's compensation laws and other like social legislation of the recent past. ${ }^{33}$ But, as has recently been expressed, if this is the basis of municipal immunity, it is surviving because fears which have never been proved justifiable have not, on the other hand, been proved unjustified. ${ }^{34}$

A variant of this fear of a depleted treasury is the position that unless there is immunity in some functions a municipal corporation could not properly perform all its functions nor feel free to assume new activities. It is pointed out that this again is an assumption which awaits demonstrable proof. ${ }^{35}$ There appears to be at least equal merit to the contention of some writers that "accompanying power with responsibility" would make for greater conscientiousness on the part of those in charge of the functions. ${ }^{36}$ As matters now stand, a negligent employee is personally liable to his injured victim, the municipality's immunity not extending to shield him. This is claimed to be inadequate protection for private citizens injured by municipal employees, because of the uncollectibility of judgments against these workmen. ${ }^{37}$ To just what extent a threat of personal liability is an incentive to careful conduct, and, if it is at all, whether the cost of such an incentive is commensurate with its results are matters upon which opinions may and do differ. ${ }^{38}$

\footnotetext{
${ }^{32}$ Peterson, Governmental Responsibility for Torts in Minnesota (1942) 26 MinN. L. REv. 293, 338.

${ }^{33}$ Rosenfield, supra note 16, at 379; Note (1938) II Rocky MT. L. Rev. 49; Note (1926) 14 Calip. L. REv. 229, 232.

${ }_{34}$ Fuller and Casner, supra note I5, at 440, 460; Note (194I) Wis. L. REv. 540; (1937) II TuLsNu L. Rev. 326. Cf. Warp, Tort Liability Problems of Small Municipalities, infra p. 363 .

${ }^{35}$ Fuller and Casner, supra note 15 , at 462 ; Clarke, supra note 31 , at 161 ; Note (1926) 14 CALIp. L. REv. 229. Mr. Walter Freedman points out: "To submit, in justification of the rule, that the immunity is necessary for the proper functioning of the city, is to propound the obvious contradiction that the agency formed to protect society is under no obligation, when acting itself, to protect an individual member of society." Liability in Tort of Municipal Corporations in Missouri (1938) 3 Mo. L. Rev. 275, 277.

${ }^{30}$ Borchard, supra note 23, at 134; Note (r926) I4 CaLIF. L. REv. 229, 23 I.

s7 Fordham and Pegues, Local Government Responsibility in Tort in Louisiana (194I) 3 LA. L. Rev. 720,721 .

${ }^{38}$ Fuller and Casner, supra note 15, at 452,459
} 
In addition to the confusion and disharmony in the raisons d'être of municipal immunity an equally serious defect is found by virtually all the commentators to lie in the difficulty of the principle's application. The formula is obviously not selfexecuting, and newer and a wider variety of municipal functions demand classification. How determine whether this function or that appertains to government or proprietorship? For this purpose the courts have called in aid various criteria and rules. In his consideration of this phase of the problem, Professor Murray Seasongood finds that "no satisfactory basis for solving the problem whether the activity falls into one class or other has been evolved. The rules sought to be established are as logical as those governing French irregular verbs."39

Thus, the distinction is often made between duties mandatorily imposed upon the municipal corporation by the state and duties voluntarily assumed. Though the courts are not explicit on the point, this distinction seems to hark back to the "arm of the state" notion. While mandatorily imposed duties are quite generally held to be governmental, the test is said to break down, for not all voluntarily assumed duties are held to be proprietary. ${ }^{40}$ It is also pointed out by the critics that, for example, it is often an optional matter with small towns and villages whether they shall have a fire department, and, if they do, the fact that they have freely chosen to do so has not compelled the courts to hold these to be proprietary functions. ${ }^{41}$ In fact the contrary is the rule. Nor can the commentators see how the dubious fact of a voluntary assumption of a duty affects the nature of that duty. They claim that in other branches of tort law such a consideration is not a determining factor of liability. ${ }^{42}$ So here again as in the case of the application of the rules of respondeat superior they complain of a distortion of otherwise well-settled principles of applicable law.

With the entrance of the municipal corporation into fields of endeavor customarily considered in the past as peculiarly private activities the courts have looked more and more to the profit aspect of such municipal ventures. Hence, it is a not infrequent proposition that if a municipal corporation reaps a pecuniary profit from the pursuit of a particular function or imposes a charge for a certain service in the course of which a tort is committed, that function or service is carried on in a proprietary capacity and liability is a consequence. The commentators ${ }^{43}$ react to this in a uniform way. They say that in other situations where tort law is applied the presence or absence of pecuniary profit to the tortfeasor is not a determinative factor. Here again they encounter difficulty in understanding the relationship between profit and the nature of a particular function. They conclude that the distinction between activities which reward a municipal corporation with a monetary return and those which bring in no

\footnotetext{
${ }^{\text {so }}$ Seasongood, supra note 16 , at 938 ; see also Borchard, supra note 23 , at 134 : "It is believed that no one of these alleged criteria or justifications is sound, and that all of them can be found to have been denied validity in decided cases."

${ }^{10}$ Peterson, supra note 32, at 339; Clarke, supra note 3r, at I63; Note (1926) 14 CALIF. L. Rev. 229, $23 \mathrm{I}$.

"I Peterson, supra note 32 , at 339.

4 Borchard, supra note 23 , at 134 ; see note 40 , supra.

is Seasongood, supra note r6, at 938; (1940) 9 BrookLYN L. REv. 34 r; Note (1936) I4 N. C. L. REv. 388; (1928) 36 Mich. L. REv. 222; Note (1926) 6 B. U. L. Rev. 290.
} 
income is no test at all but is simply another means by which the courts can escape the rigors of the common law rules. They also suspect that the presence of profit helps allay the fear of a depleted exchequer. ${ }^{44}$

A related test in arriving at the choice between "governmental" and "proprietary" is the local benefit inquiry. That is, if the function reflects to the advantage of the public generally, it is governmental; if its pursuit brings benefit particularly or peculiarly to the municipal community, it is a function carried on in the proprietary capacity. Carried to its logical extreme this test would, in the opinion of some of the writers, obliterate the distinction between governmental and proprietary functions, or, at least, would cut across the lines as presently drawn. It is stated ${ }^{4 \sigma}$ that nothing could be more to the peculiar and immediate benefit to the municipal inhabitants than their fire and police departments, functions which have quite consistently been classified as governmental. Moreover, it has been said, the fact is that all municipal functions which benefit the public generally and those enjoyed more exclusively by are now, with public funds. With the tendency for government to become more and more paternalistic any benefit to a particular locality is a benefit to the state. ${ }^{\mathbf{4 0}} \mathrm{Just}$ where the line should be drawn is not indicated by the cases. The distinction between functions are for the public benefit, for otherwise they could not be financed, as they a particular locale is thought to be more understandable as one other aspect of the inarticulate premise of fairness; if the community enjoys a service more or less restricted to it, it is but fair that it should bear the losses incurred in its maintenance. ${ }^{47}$

2. Discretionary and Ministerial Functions. When not used substitutionally for the more usual governmental-proprietary formula, the distinction between discretionary and ministerial acts is seized upon by the courts as a rational basis for determining municipal liability for tort. ${ }^{48}$ If the tort was committed in the course of an activity involving discretion of a legislative or judicial nature, no liability obtains; but if occasioned in the course of a ministerial function, there is liability. Professor Borchard's analysis leads him to assert that "the distinction ... has justification only to the extent that deliberation and action as to policy is legislation and hardly an operative fact imposing legal duties, and for the exertion of power in determining policies it would be inappropriate to predicate liability." 49 If the distinction were consistently applied and the governmental-proprietary test forgotten it should logically impose liability for all acts performed in execution of the legislation adopted under the discretionary power. It would thus do away with most of the distinctions between governmental and proprietary functions. "This," says Mr. Borchard, "perhaps is the soundest basis for predicating legal responsibility."

4 (1936) 4 U. of PitTs. L. Rev. I38.

${ }^{45}$ Note (r94 $\mathrm{X}$ ) Wis. L. Rev. 540, 544; Note (1936) I4 N. C. L. Rev. 388; Note (1927) 75 U. or PA. L. Rev. 555 .

${ }^{20}$ Borchard, supra note 23 , at 136 .

${ }^{27}$ Note (1938) 24 W. VA. L. REv. 430; (1936) 28 GEo. L. J. 1027, 1029; Note (r936) I4 N. C. L. REv. 388, 393; (1930) I7 VA. L. Rev. 8x.

${ }^{13}$ Peterson, supra note 32, at 296; David, supra note 23, at 73; (193I) 15 Mins. L. Rev. 248.

${ }^{43}$ Borchard, supra note 23, at I35; see also Note (1938) 23 Iown L. REv. 392, 395.

${ }^{50}$ Borchard, supra note 23 , at $\mathrm{r} 35$. 
been largely restricted to cases involving injuries arising from a failure to supply a service which the municipality is authorized, but not bound, to adopt; and to cases where the question is whether the injury arose out of a defect in the plan of construction as distinguished from negligence in the maintenance of the service. ${ }^{51}$ Thus, a municipality may be authorized to construct a sewer system. Its decision to do so. or not is a legislative matter, and it will not be liable for injuries caused by its decision not to supply the system. Its choice of one of several plans of construction is a matter of discretion, somewhat judicial, so that for injuries traceable to defects inherent in the plan, there is also usually no liability. Maintenance of the system is a mere ministerial function; hence liability attaches for negligent conduct in this phase of the activity. However, if the service is considered or has been previously classified as governmental, the courts fall back on the governmental-proprietary distinction to decree immunity even for injuries caused by negligent maintenance. ${ }^{52}$ Accordingly, the discretionary-ministerial distinction operates to cut down the area of liability permitted by the governmental-proprietary formula. Thus, Mr. Peterson suggests that what "seems to have been done, although not articulately," by recourse to the discretionary-ministerial distinction, "is to substitute a rule of reasonableness" in cases of non-governmental functions so that the municipality is subjected to liability only when its action is unreasonable.53

3. The "Active Wrongdoing" Test. Before setting out New Jersey's "active wrongdoing" test, it might be of interest to mention a yet more unusual test existing at least by dicta in that state. The courts there, feeling strongly the wisdom of the maxim that there is no wrong for which the common law provides no remedy, have announced that whenever an indictment will not lie for a breach of a public duty, a civil action will lie; and the corollary, later added, where an indictment will lie, a civil action for damages will be dismissed.54 In a joint article, Messrs. Weintraub and Conford point out that "if this test of liability were faithfully applied, it is apparent that the immunity of a municipality would be greatly circumscribed, for there are many instances of neglect and negligence that would not support an indictment." "5o However, "as a matter of fact, notwithstanding constant reiteration of the statement that a civil action may be maintained where an indictment does not lie," apparently only two cases actually allowed recovery on that theory, and even in those the result may be otherwise explained.56

Nevertheless, New Jersey does occupy a unique position. This it does by virtue of its "active wrongdoing" test. The courts of that state go along with the common

\footnotetext{
${ }^{01}$ Peterson, supra note 32, at 297; David, supra note 23, at 78-89; (1939) 24 Iows L. Rev. 384; (I937) 26 Mrat. L. REv. 227 .$$
{ }^{2} \text { Peterson, supra note } 32 \text { at } 296 .{ }_{63} \text { Id. at } 298 .
$$

This principle was first suggested in Jersey City v. Kiernan, 50 N. J. L. 246, I3 Atl. I70 (1888). The court in that case said, at p. 250: "Consequently, in the case at hand, as the mischief to the community, if any, is not of a magnitude sufficient to justify an indictment, while at the same time it damages the property of an individual, it is obvious that unless such a suit as the present one [civil suit for damages] will lie, the wrong cannot be redressed by any method known to the law:" (Italics and brackets supplied.) The converse of the proposition was added later in Waters v. Newark, 56 N. J. L. $36 \mathrm{r}, 28 \mathrm{Atl}$. $7 \mathrm{r} 7$ (1894).

${ }^{\circ}$ Weintraub and Conford, Tort Liability of Municipalities in New Jersey (1934) 3 MERCER BEASLEY L. Rev. I42, I59.

${ }^{50}$ Weintraub and Conford, supra note 55 , at $x 63$.
} 
law rule that a municipality is exempt from liability for damages resulting from its neglect to perform, or from its negligent performance of, public duties, but it adds, if the negligence can be termed wanton, then there is liability. This would at first blush seem to open a wide avenue of escape from immunity. ${ }^{57}$ But, restriction of the applicability of the ordinary rules of agency rather effectively limits the exception. The active wrongdoing must be "chargeable to the municipality in order to render it liable: the doctrine of respondeat superior does not apply to public employments." $\$ 8$ An authorization for the particular conduct complained against must be found before such wanton negligence will be attributed to the municipal corporation. ${ }^{50}$ The "active wrongdoing" test has received the apparent approbation of at least one student writer, but even he expressed dissatisfaction with the lack of consistency with which it had been applied in its home state. ${ }^{60}$ It is obvious that its application is not easy. Nor does it entirely avoid the difficulties of the classification of the functions in terms of public and private. ${ }^{61}$

4. The Historical Test. Though rarely used by the courts, it is sometimes said that the historical test might possibly be used as a determinant of the nature of a given function. Thus, is this function one which has usually been undertaken by municipal corporations or other units of government? If so, it is a governmental activity. But, as Mr. Peterson says, "Obviously this cannot be carried too far. It was not until I8Ig that the first municipal police force was established in London, but police protection has almost uniformly been held to be governmental in character."02 Further, if it be remembered that street and sidewalk maintenance has almost universally and from ancient times been considered a concern of government and yet the general holding in street and sidewalk accident cases is that a municipality is liable for negligence, a fair share of the cases could not be decided as they are, nor reconciled to this principle. "The lack of consistency in historic reasons," says Professor Seasongood, "is therefore self-evident."

\section{Some Municipal Functions and Their Classification}

It is now proposed to present several municipal functions and the classification accorded them. The list is by no means exhaustive, but it is meant to be fairly illus. trative, first, of the older and newer functions, and second, of functions reflecting, respectively, judicial agreement and discord.

I. Police. There is a surprising degree of unanimity among the courts in classifying police departments as governmental functions. Reviewing the cases, however, the

${ }^{57}$ That it has a tendency to widen the area of liability, see cases discussed by Weintraub and Conford, stipra note 55, pp. 165-167.

${ }^{68}$ Florio v. Jersey City, ror N. J. L. 535, 537, I29 Atl. 470, 47 (1925). (Italics supplied.)

${ }^{60}$ Weintraub and Conford, supra note 55 , at 163 .

${ }^{\circ 0} \mathrm{See}$ (1937) 32 ILL. L. REV. 372, n. 13, where the student writer says: "This doctrine has promising possibilities, but the results of its application have been disappointing. The courts have called active wrongdoing what appears to be simple negligence." With this compare (1940) 25 MiNN. L. REv. 115, II6, where the student writer says of the test: "It seems artificial and merely adds to the existing confusion to make the distinction between misfeasance and nonfeasance the test of a municipality's liability." Sce further (1939) 55 LAw Q. REv. Io.

e1 This must be so, for the distinction has reference only to "public functions."

62 Peterson, supra note 32, at 342. 
commentators do not find the same degree of unanimity in the reasons given to support the classification, any one or more of the several rationales given above being used to justify the judicial appraisal of this activity. ${ }^{64}$ While some commentators recognize that at common law there is no ground of tort liability for a mere failure to enforce law or suppress crime, they criticize the judicial position which grants immunity even for grossly negligent and wilful acts of police officers. ${ }^{65}$ There is some report, however, of an occasional judicial deviation where police officers have caused injuries while in the pursuit of a corporate activity. ${ }^{66}$

2. Fire Departments. Here too the critics find a remarkable accord in calling a fire department a governmental function. Almost every act of omission and commission, whether due to the municipal corporation as a body or to the occasional acts of individual firemen, and whether or not concerned immediately with the operation or maintenance of the department, is covered by the privilege of immunity. The courts sometimes support immunity by recourse to the mandatory nature of the activity and sometimes they present the reason that a fire department is carried on for the benefit of the municipal corporation and its citizenry. Mention has already been made of the critics' answers that the first reason is far from universally true, ${ }^{67}$ and that the second rationale is often given as a justification for liability. ${ }^{68} \mathrm{~A}$ student note has also suggested that the classification of a fire department as governmental is inconsistent with its local voluntary beginnings. ${ }^{69}$ Moreover, there have been both judicial and statutory inroads upon the rule of immunity. ${ }^{\mathbf{7 0}} \mathrm{A}$ distinction has been made between injuries inflicted on the way to a fire where speed is essential and those occurring on the return trip. ${ }^{71}$ Still, the aura of immunity hangs so heavily over fire departments that in some jurisdictions they have been exempt from liability even for torts committed in the course of practice drills and equipment-testing. ${ }^{72}$ It is a matter of note that the applicability of the principle of sovereign immunity to a municipal corporation has received its most serious attack in two fire department cases. ${ }^{\mathbf{7 3}}$

3. Water, Gas and Electricity Service. The furnishing of water, gas and electricity is in nowise a field unique to municipal ownership or operation. These activities, perhaps more than others, partake of a commercial nature. They are, therefore, quite usually considered proprietary functions. The courts in imposing liability usually emphasize their voluntary nature and stress the profit or local benefit resulting to the municipal corporation and the city's inhabitants from their operation. However, the same main which carries water into the home of Citizen Doe may also carry it into the hydrant which guards his house. For injuries attributable to negligence in

" Borchard, Government Liability in Tort (1925) 34 Yale L. J. 229, 240; (1938) II Rocky MT. L. REv, 49, 51 .

os Borchard, supra note 64, at 24I; (I934) 33 MICh. L. Rev. I3r; Note (1932) 42 YALE L. J. 241.

ac Borchard, supra note 64, at 24I; (1936) 8 Mrch. L. J. 513; see also (I928) 28 Col. L. REv. IIII; (1934) 33 Mrch. L. Rev. 13T.

${ }^{68}$ Supra note 45 and text.

${ }^{67}$ Supra note 40 and text.

${ }^{70}$ David, stpra note 23, at 386 et seq.; (I938) 27 Cazif. L. Rev. 57; (1933) 7 TEMp. L. Q. 253; (1932) 7 Tulane L. Rev. I48; (I930) 9 Tex. L. Rev. 68.

${ }_{71}$ Fowler v. City of Cleveland, roo Ohio St. 158, 126 N. E. 72 (1919); see also Feezer, supra note I6, at 820 et seq.

72 (1932) 26 IL.L. L. REV. 709.

${ }_{73}$ Workman v. New York City, r79 U. S. 552 (I900); Fowler v. City of Cleveland, supra note 7r. 
the former aspect of this activity Citizen Doe may recover; for injuries traceable to negligently maintained pressure in the hydrant his case for recovery is not so clear. Some courts distinguish and find that this latter phase is connected with fire protection and hence governmental. The same distinction appears with respect to electricity: one line may carry electricity into a private home, another on the same pole may feed a street lamp. It makes a difference, then, to some courts whether the repairman was burned to death because he touched one wire or the other. Such distinctions as these, and there are others, are used by the critics as apt illustrations of the arbitrary results of the governmental-proprietary formula. ${ }^{74}$ Adverting to the emphasis placed upon the fact that these utilities are profit-making ventures the critics discover that it does not seem essential to the end result that the municipality shall realize an actual profit from the business; that it is enough if a charge, even though it be merely cost-defraying, is made for the service. ${ }^{75}$ Whether or not a charge will be made for a particular service, they say, is more often than not a matter of policy with the council or governing board. They finally contend that if the courts were fully aware in other instances that the "taxpayer pays for all municipal enterprises and that they must all be legally justified as accruing to his benefit," then the distinction between governmental and proprietary functions would be dispensed with. ${ }^{\text {T6 }}$

4. Sewers and Garbage Disposal. There is apparently neither unanimity in the results reached nor the avenues used to reach them when the complaint is for negligence in the maintenance of a sewer system or garbage and refuse disposal. Some courts classify either or both as governmental, finding a close connection between such activity and the public health. To Professor Borchard the fact of a driver of an ash cart or garbage wagon being engaged in the "sovereign governmental work of safeguarding the public health" is a "somewhat startling proposition."77 There are courts, however, which feel compelled by the presence of a monetary fee for the services to find them proprietary. ${ }^{78}$ Some factual situations permit a final group of courts to escape entirely the necessity of classification by finding a nuisance; but here, of course, the distinction between personal and property injuries asserts itself. ${ }^{70}$

5. Streets, Sidewalks and Bridges. Nothing. has been for so long considered a concern of government than the construction and maintenance of ways. So, the critics argue, the logic of the theory of dual capacity would seem to command that there be no municipal liability for injuries resulting from the negligent construction or maintenance of streets, sidewalks and bridges. ${ }^{80}$ Yet the undoubted weight of au-

\footnotetext{
${ }^{74}$ Peterson, supra note 32, at 293; Tooke, supra note 16, at 102; Seasongood, supra note $\times 6$, at 938 ; Freedman, supra note 35, at 280; Note (1937) 32 ILL. L. REv. 372; Note (1935) I5 B. U. L. Rev. 638; (1927) 6 N. C. L. REv. 100; (1927) 16 KY. L. J. 77; (1926) 4 N. C. L. REv. 136.

${ }^{75}$ Fordham and Pegues, supra note 37, at 729; Peterson, supra note 32, at 354 .

${ }^{70}$ Borchard, supra note 64, at 253; see also Note (I926) 6 B. U. L. REv. 290.

77 Borchard, supra note 64 , at 250 .

78 (I940) 28 GEo. L. J. 705; (I935) 13 ChI-KENT L. Rev. 37I; (I93I) 9 NeB. L. BuLl. 349.

${ }^{79}$ (1936) 35 Mich. L. REv. 157; (1933) 33 Cot. L. REv. 747; sec, for further distinctions, (1929) 3 TeMP. L. Q. 328; (1929) 20 NAT. Munic. Rev. 370.

${ }^{80}$ See notes 62 and 63 , supra; see also (1939) 14 Tulıne L. Rev. 132; (1938) 1o Miss L. J. 175; I6 B. U. L. Rev. 444 ; (I936) 4 J. B. S. KAN. 322; (I933) 20 VA. L. REv. 238.
} 
thority is to the contrary. Even in the absence of statutes imposing liability the courts as a unit deny immunity and hold that a city, though not an insurer of its ways, is yet subject to a duty of reasonable care in their construction and maintenance. While most courts recognize this as exceptional, others rationalize liability as an incident of the exclusive control enjoyed by a city over its streets, sidewalks and bridges. The critics find this fallacious because a municipal corporation cannot escape liability for wrongs suffered by negligent conditions and disrepair in its ways by delegating their construction or maintenance to a private person or private corporation. ${ }^{81}$

6. Traffic Signals. Whereas liability for injuries from negligent street maintenance has been so uniformly imposed, when the somewhat similar problem of traffic signals and regulations comes before the courts, liability is generally denied. The reason for classification of these functions as governmental vary: some courts assert that traffic regulation is primarily for the benefit of the general public; others place immunity on the ground that the duty to regulate traffic is mandatorily imposed by the legislature; and lastly some interpret street maintenance as having reference only to the physical condition of the streets. ${ }^{82}$ However, it is suggested that traffic signals and traffic regulations are so intimately related to street maintenance and involve such cognate problems and policy considerations that the same rules ought to be applied. ${ }^{83}$ Discussing the problem, Mr. Joseph F. Murray asserts that he can find no reason of logic or policy to justify the individual sacrifices resulting from immunity in this field. ${ }^{84}$

7. Parks, Swimming Pools and Recreation Centers. Almost every commentator ${ }^{85}$ sees in the cases involving parks, swimming pools and recreation centers the tendency to constrict the area of municipal immunity. While many of them admit that a numerical majority of the cases fix these functions as governmental, they assert the later cases to be preponderantly of the opposite conclusion. Doubt of this has been expressed. ${ }^{86} \mathrm{Be}$ that as it may, there is a conflict between the old and the new. Those courts which classify these facilities as governmental do so usually on the ground that they have an intimate relation with the public health or, more broadly, the public good. They explain away admission fees as incidental, expense-defraying charges. ${ }^{87}$ But it is this element of a charge which is seized upon by the courts of other mind.88 Absent the fee element, some courts have gone so far as to work out liability on a

\footnotetext{
${ }^{81}$ Note (1930) 9 Tex. L. Rev. 53; see also Sahm, Municipal Liability in Pennsylvania for Defective Streets (194I) 45 Dick. L. REv. II3, II4. Some further discussion of this group of municipal functions can be found in the following: (I94I) I3 Rocky MT. L. Rev. 360; (1940) 16 TeNs. L. REv. 249; (1940) 8 Duke B. A. J. 124; (1938) 5I Harv. L. Rev. I30I; (1935) 7 Miss. L. J. 530; (1930) 44 Harv. L. Rev. 302; (1929) I5 VA. L. REv. 595.

${ }^{8}$ Murray, Recent Tresds in Municipal Tort Liability (1940) 5 Legar Notes on Local Govt. 353, 354; Note (1939) 23 Mare. L. Rev. 216; (1938) II Rocky MT. L. Rev. 128; (1934) I3 Tenn. L. REv. 59.

${ }^{83}$ Murray, supra note 82; (1939) 23 MARQ. L. Rev. 216; (1937) 21 MiNN. L. Rev. 459; (1935) I3 N. C. L. REv. 245; but see (I929) I5 VA. L. Rev. 595.

"Murray, supra note 82 .

${ }^{65}$ For instance, see (1938) 44 W. VA. L. Q. 159; Note (1936) 34 MrCF. L. Rev. I250; Note (1936) I4 N. C. L. Rev. 388; (1934) I9 St. Lours L. Rev. 257; Note (1929) 3 CinN. L. Rev. I83.

${ }^{80}$ (1938) 24 VA. L. REV. 430.

87 (I928) 2 TENM. L. Q. I90.

${ }^{88}$ (Ig29) 6 N. Y. U. L. Q. REv. 477.
} 
nuisance ground. ${ }^{89}$ The local benefit theory is also used to impose responsibility. ${ }^{90}$ Occasionally a court will make the blanket expression that municipal property must be managed with the same care and liabilities as are attendant on privately owned property. ${ }^{91}$ Every writer on the subject commends the growing tendency to impose responsibility for the careful operation and maintenance of parks and recreational facilities; "to hold otherwise is to establish a rule of law which puts children at the mercy of dangerous conditions of which they are not aware and over which they have no control." 92

8. Education. The general position taken by the judiciary in school accident cases is that education is a governmental function and hence for all injuries arising from this activity neither the school district, the board of trustees, nor the municipality shall be liable. To support their conclusion the courts announce the "trust fund doctrine," i.e., that there is no authority to use school funds for any purpose other than education. ${ }^{93}$ Despite the fact that "the public school system in the United States ... constitutes the largest single business in the country, [it] is still under the domination of a legal principle which in great measure continues unchanged since the Middle Ages. . . ."94 Considering the dominant role of the school in the life of school children and the community in general, Mr. Harry N. Rosenfield charges that "the principle [of sovereign immunity] is applied with complete disregard of the specific facts, in a more or less blanket fashion, regardless of whether the injury was the result of a falling building, or whether the pupil is killed by a swing. . . ."95 However, he does find that there have been both statutory ${ }^{98}$ and judicial ${ }^{97}$ deviations, the latter following a pattern of denying immunity to the extent that there is insurance coverage, or by finding a trespass to real property, or by applying the nuisance doctrine, or, as the New York courts have done, ${ }^{08}$ by holding school boards liable by imputing to them the actionable negligence of their agents and employees for certain so-called non-delegable duties.

9. Municipal Airports. The usual view taken of a municipal airport is that it is a commercial enterprise, a proprietary function. The commentators' review of the cases shows the courts on uncertain grounds when dealing with this most recent municipal activity. It has been said that the various courts have likened an airport to public streets, ${ }^{99}$ to docks and bridges, ${ }^{100}$ and to the city's transportation system. ${ }^{101} \mathrm{~A}$ study of the municipal airport situation revealed that legislatures have already moved to curb liability. This legislative reaction is understood as a fear that the mounting costs of damages recovered for injuries caused by the construction and maintenance

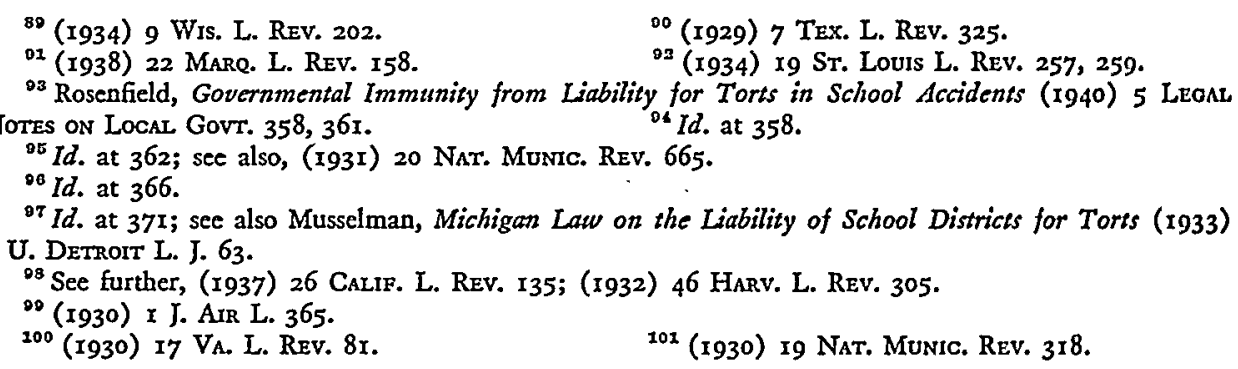


of airports might stifle an experimental and perhaps desirable enterprise. One writer at least has urged that a municipality ought to be liable for the torts arising from this activity just as is any commercial entrepreneur. ${ }^{102}$

\section{UITRA VIRES}

Though the aggrieved plaintiff succeeds in establishing the proprietary nature of the particular activity which caused him harm, it may be necessary for him to surmount yet an additional hurdle. This is the plea of ultra vires. If the act relied upon as giving the cause of action is one wholly beyond the corporate power or authority, the plea of ultra vires will defeat the prayer for damages. However, the commentators complain that the courts have failed consistently to respect the distinction adhered to in private corporation cases between acts wholly beyond or repugnant to authorized power or scope, and acts, which, though abusive of acknowledged authority, are yet incidental to or consequent from granted powers. They therefore urge that the doctrine of ultra vires, if applied at all to municipal functions, be applied in the same manner as it is now applied to private corporations. ${ }^{103}$

\section{Statutory Changes}

If there is a constitutional provision, statute or ordinance, either permitting suit, imposing liability, or otherwise settling the question, there is no need of further inquiry into the nature of the function involved. ${ }^{104}$ While it has been said that the more recent legislation signifies a yielding to the pressure of persistent criticism, ${ }^{105}$ the statutory change has not all been along the line of extended liability. ${ }^{106}$ But, although no one has made an actual count, opinion has it that the tendency of legislation is away from immunity. The judicial reception of these statutes has not been consistent. The courts, as one commentator demonstrates, have not always construed them so as to broaden the scope of those statutes which impose liability and constrict the areas of those which confer immunity. ${ }^{107}$ While Mr. Leon David's study of the municipal tort law of California found that the existence of a liability-extending statute created in both court and jury an attitude of the "lid's off" with respect to both the situations which it covered and the amount of damages granted, ${ }^{108}$ elsewhere the statutory construction escape has not been exploited, ${ }^{109}$ in fact, in some instances, has been actually scorned.110 Mr. David concluded that it is no simple task to draft a statute which will "meet the situation fairly for the litigant and which

${ }^{103}$ (1932) 2I NAT. Munic. Rev. 330; see further, on the subject, (1937) I5 CHI-KeNT. L. REv. I55; (1937) 8 J. ArR. L. 270; (I930) I J. AIR L. 42 r.

${ }_{103}$ Peterson, supra note 32, at 299; Fordham and Pegues, supra note 37, at 745; Borchard, supra note 64, at 255; Note (1929) I4 CoRn. L. Q. 35I; (1929) 6 N. Y. U. L. Q. Rev. 477; (1927) 2 WAsh. L. REv. 136; but of. Note (1934) 8 T'EMP. L. Q. 359, 360.

104 Seasongood, supra note 16, at $918 .{ }^{105}$ Note (I93I) x6 CoRN. L. Q. 359, 360.

100 Thus, I. W. Coleman, in Note (1934) 13 Mrch. S. B. J. 165 , concludes: "It is apparent that there is no tendency on the part of legislatures to impose plenary liability on public corporations for their torts."

${ }^{107}$ Note (1935) 10 TeMP. L. Q. 75.

${ }^{108}$ David, Municipal Liability in Tort in California (1934) 7 So. CarIF. L. REv. 372, 467.

${ }^{100}$ (1936) 3 I ILI. L. REv. 28I; (1933) 7 Temp. L. Q. 253.

${ }^{120}$ Note (I932) 42 Yare. L. J. 24I; of. (1934) 33 Mich. L. Rev. I3I. 
will at the same time protect the public from spurious and unconscionable claims, and from skyrocketed damages." 111 He suggested that it might be necessary and even desirable to limit the amount of damages collectible for particular injuries. ${ }^{112}$

A type of statute which at least thirty states have already adopted is the notice or "short statute of limitations" law. ${ }^{113}$ The notice contemplated by these statutes is to be distinguished from that notice, actual or constructive, of defects and conditions of disrepair and danger in streets and sidewalks, which is a necessary element in the proof of negligence. ${ }^{114}$ Rather, these statutes provide that notice of claim against the municipality must be filed within a prescribed period of time after which the claim is barred. The policy of such statutes, one municipal corporation counsel ${ }^{115}$ says, is ( $\mathrm{x}$ ) to afford the city an opportunity to make timely investigation in order to disprove fraudulent claims; and (2) to give it a chance to settle meritorious claims out of court. The several writers who have considered these notice statutes believe that, with the tendency toward greater areas of liability, some such mechanism is needed to guard against "trumped-up claims."116 Discontent with the judiciary's failure to grasp the policy of these statutes has been expressed. Mr. Henry S. Sahm urges that if these notice laws are to serve their purpose at all they must be construed as imposing a condition precedent to suit; that the mere filing of the complaint and summons should not be considered proper or sufficient notice of claim; and that failure to give the prescribed notice within the time specified should be held to bar the claim.117

\section{The Critics Propose and Suggest}

The almost unanimous voice of writers on the tort law of municipal corporations echoes with the conviction that relief from the present state of confusion can come only from the legislatures. ${ }^{118}$ It is interesting to note that in I92I Professor Harno placed his faith in the judicial branch to rid the law of this curious anomaly. ${ }^{110}$ Since then the persistent refusal of the courts to go beyond gossamer distinctions and arbi-

${ }^{111}$ David, supra note 108 , at $46 \%$.

122 Ibid. For a discussion of the effect of statutes and provisions limiting the amount of municipal indebtedness on the collectibility of tort claims against municipal corporations, sec (1936) 35 Mich. L. Rev. I20; (1935) $20 \mathrm{ST}$. Louis L. Rev. 287. For one reaction to exemplary damages against the municipal corporation, see (I94I) 40 MICH. L. Rev. 135.

${ }^{213}$ For citations to these statutes, see Sahm, Tort Notice of Claims to Municipality (1942) 46 Dick.

L. Rev. I, n. 2; also, David, stupra note 108, at 339, n. 644 .

114 For example, see Sahm, supra note 113, at 118 ; DeGraff, Snow and Ice: A Discussion of Liability under the Laws of New York (1936) 21 Cons. L. Q. 436.

${ }_{115} \mathrm{Sahm}$, stipra note $\mathrm{I} 13$, at 2,3 .

${ }^{210}$ Ibid.; Note (I937) II CinN. L. Rev. Ix3; (1937) 24 VA. L. REv. 86.

${ }^{217}$ Sahm, supra note $\mathrm{II}_{3}$, at ro.

${ }^{118} \mathrm{Mr}$. Seasongood says: "Examples of conflict of decisions and unsatisfactory reasoning in this field could be multiplied indefinitely. The doctrine is .... so thoroughly written into the books by judicial decision that it requires what George Gissing called 'prancing optimism' to hope that it can be expunged by departures from the rule of stare decisis. . . ."

"Constitutions should be amended and statutes passed doing away with city exemption from liability based on governmental immunity, and in home rule cities ordinances for the same purpose should be cnacted if the state legislature is dilatory in promulgating suitable statutes." Seasongood, stpra notc 16, at $94 \mathrm{r}, 944$.

${ }^{110}$ Harno, supra note II, at 42; see also GoonNow, op. cit. supra note 6, at 183 . 
trary exceptions has caused a complete reversal in commentator position. Thus the first point of agreement is the need of immediate legislative attention. ${ }^{120}$

Substantial agreement exists also in the belief, developed without benefit of factual study, ${ }^{121}$ that the area of liability could be extended without serious hindrance to efficient, progressive service and without greatly increased costs. ${ }^{122}$ But some writers caution that there may be areas within which considerations of policy commend immunity; ${ }^{123}$ or, in Professor Edwin F. Albertsworth's words, "in general, tort liability should be imposed upon the city just as upon a private corporation or a private citizen, except where there are certain justifications, based on strong countervailing social interests, which excuse or exempt the city from the legal consequences of its acts." ${ }^{24}$ But it is felt nonetheless that there is nothing ultimate about the distinction between governmental and proprietary functions which can be relied on to delimit these possible zones of immunity. ${ }^{125}$ "Here again, as in other fields," to continue with Mr. Albertsworth, "it is the injury to the individual which should be of paramount and primary consideration, not the character of the person who causes it."128 Though there appears to be a surprising degree of judicial accord in the classification of several municipal functions, it is a common suggestion that it may be time to re-examine even these few to determine whether the supposed considerations of policy still obtain..$^{127}$ The least that could be done, one of them maintains, is a cataloging of those functions to which responsibility should attach. ${ }^{128}$

It is not infrequently said that a sound public policy forbids the extension of tort liability into the fields of the criminal law and the determination of policy. ${ }^{129}$ There is believed to be a social interest in the maintenance of law and order which makes it unwise to expose the city to liability for the unlawful acts of its police. Also, for the omission of certain public functions, at least where there is no duty running to the injured private person, there should be no liability. At least one writer would include fire-fighting activities within the province of immunity. A social interest in the protection of property and lives of others, he believes, outweighs the considerations for individual protection, at least when the fire department is engaged in "the duty of sending fire engines to the scene of the fire as quickly as possible."130 It is usual to find, in this group, statements that a municipal corporation should be held liable for

\footnotetext{
${ }^{120}$ One student writer asserts that there is an overwhelming opinion throughout the world in favor of liability. (I932) 42 YALE L. J. 24I. See also Fordham and Pegues, supra note 37, at 755; Note (r94I) WIs. L. Rev. 540, 569; Clarke, supra note 3r, at 174; Barnett, The Foundations of the Distinction Between Public and Private Functions with Respect to the Common-Law Tort Liability of Municipal Corporations (1937) I6 Ore. L. REv. 250; Freedman, supra note 35; but of. Note (1936) 8 Miss. I. J. 513.

${ }_{121}$ Statistical studies are of recent date. See note 142 , infra.

${ }^{122}$ See notes $33,34,35$, and 36 , supra.

${ }^{123}$ Longstaff, Governmental Liability in Tort (I940) 9 S. D. B. J. II5; Note (194r) I6 Notre DaMe LAWYer 365; (1940) 29 Geo. L. J. 705; (1939) 24 Wash. U. L. Q. 425; Note (1938) 23 Iowa L. J. 392; (Ig29) I4 CoRN. L. Q. 35 I.

134 Albertsworth, New Interests in the Law of Torts (1922) ro CAIIF. L. REv. 46r, 484 .

${ }^{126} \mathrm{Cf}$. Fordham and Pegues, supra note 37, at 730. ${ }^{126}$ Albertsworth, supra note 124, at 485 .

${ }^{127}$ For example, see Borchard, Mutricipal Liability in Tort in Swimming Pools (r939) 4 LEGAL. Nores ON LOCAL GovT. 385.

${ }_{120}$ (1940) 28 GEO. L. J. 705; (1939) 24 IOWA L. REv. 384.

${ }^{130}$ Albertsworth, supra note I24, at 485 .

${ }^{128}$ Longstaff, supra note 123 .
} 
most injuries arising from property ownership. ${ }^{131}$ The very ownership of property and its use involves a relation to the outside world, and, consequently, in Professor Goodnow's analysis, ${ }^{132}$ the city should be responsible.

"A sensible medium" between complete liability and complete immunity has been suggested as possible, the line to be drawn to divide, on one side, "those instances in which the damage results from positive conduct of a nature so flagrant as to seem unnecessary to the ordinary functions of government," and, on the other, such activities where because of the impossibility of constant supervision and the necessity of emergency action it would be unfair to impose liability. ${ }^{133}$ There is in this a hint of the "active wrongdoing" test. The fault seems to lie in the probability that a like degree of confusion would accompany the determination of activities on one side of the line or the other.

Having his eye on the practical fact that the right of action which the injured individual has against the municipal employee is usually an unremunerative remedy, one writer ${ }^{134}$ has suggested that study of the effectiveness of official bonds might reveal a means whereby the law of municipal corporations could be brought into better conformity to the modern law of private liability in tort. There are, of course, statutes requiring the bonding of certain officials. The suggestion seems to envisage a more or less universal bonding scheme. While, this would alleviate one of the defects of the present situation, it would not completely eliminate the necessity of classification in terms of governmental and proprietary functions. ${ }^{135}$

Several municipal corporations have resorted to public liability insurance, giving the injured individual a direct recourse to the insurer. This again does not escape the difficulties of the common-law rule, for the insurer's liability is usually dependent on the liability of the insured. Writing of the situation in Louisiana, Messrs. Fordham and Pegues found the courts construing the insurance contract liberally so as to hold the insurer liable when it was at all possible to do so. They conclude that in doing this the courts have created "a needlessly illogical imbroglio," and that public liability insurance was not the best way out of the prevailing confusion. ${ }^{138}$

Mr. Fuller and Mr. Casner in their recent study ${ }^{137}$ adverted to reimbursement statutes as a possible means to avoid the harshness of imposing personal liability on the negligent agent or employee and, at the same time, to insure the injured person of ultimate recovery. Any extension of the reimbursement procedure, they believe, should be examined in the light of its specific purposes and the general purposes of tort law. Its advantages should be balanced against the general desirability of promoting careful conduct, for it may be that the threat of personal liability without

${ }^{132}$ Id. at 486.

${ }^{133}$ (1937) 32 Irx. L. Rev. 372, 372; cf. Chattin, Tort Liability of Municipal Corporations in Indiana (1935) Io IND. L. J. 329, wherein the writer suggests a balancing of the interests in each case as a way out.

${ }_{132}$ (1932) 2 I Nat. Munic. Rev. I88; see also Note (1926) 14 Calif. L. Rev. 229.

136 Tooke, supra note $x 6$, at $x \times 7$.

${ }^{189}$ Fordham and Pegues, Local Government Responsibility in Tort in Louisiana (1941) 3 LA. L. Rev. $720,748$.

${ }_{187}$ Fuller and Casner, Municipal Tort Liability in Operation (1941) 54 Harv. L. Rev. 437, 451. 
hope of reimbursement is some incentive to non-tortious conduct. They find, however, several deeper defects in this alternative. First, officers and agents have been held to enjoy an immunity when certain governmental functions were involved. It thus seems that in many cases resort to the conceptualism of the common law would not be avoided. Second, there is the element of delay. Before reimbursement can be made there must first have been a successful court action to establish the personal liability of the individual defendant, and only thereafter will come an administrative decision to reimburse him. "In any event, the purposes of tort liability are not more adequately solved by the indirect municipal liability arrived at through the reimbursement procedure."138

Therefore, to continue with Fuller and Casner's conclusion, "the present hit-andmiss application of partial tort liability" ought to be "immediately replaced with a rule of complete liability. ${ }^{139}$ They and many others believe that municipal liability ought to be coextensive with its activities. ${ }^{140}$ This group see no present-day reason why a municipal corporation should not be subject to the same liability as an individual. Nor do they feel a fear that complete liability would restrict any of the activities now or which may later be assumed by the municipal corporation. It is their contention that the public has "somehow tolerated the immunity rule, because fears that have never been proved justifiable have, on the other hand, never been adequately proved to be unjustified." 141

Confident of their position, many of the better known critics urge a thorough study of the probable effects of a rule of complete liability. The present substantive law of several states has already received thorough study and analysis. Recently several statistical studies have been made and the results are interpreted as eliminating the supposed arguments for the immunity rule. ${ }^{142}$ "Should the feared abuses appear in any area under a rule of complete liability, they could then easily be remedied on the basis of fact rather than fears." 143

Thus, whatever be the trend of the cases, the trend of commentator opinion is clear. The present state of things is one of confusion, fears, and assumptions, and often injustice. The problem is viewed as one in which considerations of fundamental social philosophy are inherent. One tenet of the social philosophy current in the literature of the subject is that unavoidable losses and risks should be allocated over as wide an area of absorption as possible. To this the losses consequent upon the day-to-day operation of the municipal corporation should be no exception.

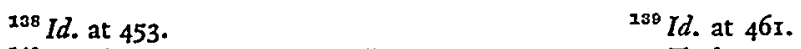

${ }^{160}$ Freedman, supra note 35; Barnett, supra note 120; Tooke, supra note I6; Feezer, supra note 16; Borchard, stpra note I3; Harno, supra note II; Rosenfield, stpra note r8; Note 194I WIs. I. Rev. 540 .

${ }_{111}$ Fuller and Casner, supra note 137 , at $46 \mathrm{r}$.

${ }^{16 s}$ See references to studies in French, Research in Public Tort Liability, infra p. 234.

${ }^{243}$ Fuller and Casner, supra note 137 , at $46 \mathrm{r}$. 